\title{
Collaborative Sociological Practice: the Case of Nine Urban Biotopes
}

\author{
Alison Rooke ${ }^{1}$ \\ Published online: 10 June 2016 \\ (C) The Author(s) 2016. This article is published with open access at Springerlink.com
}

\begin{abstract}
This paper examines the socially engaged art project Nine Urban Biotopes (9UB), an international exchange between European and South African cultural organisations. Two artist residencies offer case studies of collaborative arts and research practice. The ways that these case studies are read as 'failures' and 'successes' illustrate the complexities of NorthSouth collaborations. This project, the partnership that sustained it and the residencies that were central to it, exemplify, in modest ways, how public sociology can be realised in modest ways in a global context. This paper shows, with examples, that whilst partnership and collaboration are emphasised in institutional and policy discourse, in practice these arrangements are filled with tension and unequal power relations between partners. An evaluative methodology premised on sociological practice allows the tensions that are inherent in partnership and collaboration to be recognised and productively interrogated. It also allows us to reimagine what 'success' and 'failure' looks like in research partnerships by working with the antagonisms that are integral to collaboration.
\end{abstract}

Keywords Art $\cdot$ Research $\cdot$ Collaboration $\cdot$ Partnership $\cdot$ Dialogue $\cdot$ International

\section{The Montreuil Residency: the Complexity of Collaboration}

South African architect Taswald Pillay spent his 9UB artist residency at a Roma camp in Montreuil, Paris. Pillay brought his professional experience of working with informal settlements in Africa to Europe. In Montreuil, he encountered a complex situation. An extended

This paper builds upon previous chapters written with Christian von Wissel for the 9UB e-book and an earlier version of this paper (Rooke and von Wissel 2015). These arose out of long and fruitful conversations in Durban, Johannesburg, Berlin, Paris and London and on flights between these places. I would like to thank Christian for his contribution to this chapter and his spirit of collaboration. The photographs in the text were taken by Christian Von Wissel and are reproduced with permission

Alison Rooke

a.rooke@gold.ac.uk

1 Department of Sociology, Goldsmiths, University of London, New Cross, London SE14 6NW, UK 
Roma family had been granted a temporary permit to live on a national cultural heritage site, on the basis of their willingness to integrate into French society. This willingness was demonstrated in previous years through their engagement with a civil association, set up by local middle class residents. The civil association suggested building a small community centre at the edge of their site, which the Roma complied with. This building was seen as a materialisation of the Roma families' willingness to integrate. However, the Roma family was ambivalent about this project. Neighbourhood relations with other Roma groups living on adjacent plots were regarded as (still) too problematic and it was felt that a shared community centre would only exacerbate such tensions. Quatorze, a not-for-profit architectural organisation with a specialism in participative and collaborative practice (and 9UB hosting partners), were invited to facilitate the conflict. Quatorze worked alongside a national school of architecture, who were running a design-build studio with students on site (see Fig. 1).

Pillay's knowledge of informal settlements generated a nuanced reading of the hidden relations between architectural ideas of housing and those of the housed. Pillay questioned the architectural desire to design and build. He recognised this troubling dynamic at play in Montreuil and halted the proposed build. He challenged the micro-politics and social sustainability of this architectural intervention. In doing so, he questioned the status of the 'gift' and the terms on which the Roma family, as well as all the other stakeholders, were included into the 'participative' process. Pillay suggested that this proposed 'gift' was in fact a manifestation of obligation and showed little understanding of the social context of Roma life. Rojas Loa (2015) accompanied the European residencies with a critical lens. Here she described how Pillay's activities unfolded:

In order to meet the expectations of a cultural centre, he proposed delaying the process. Together with Quatorze, he organised a workshop with the children in order to see if, through such a workshop, he could find out what the Roma family really wanted and needed. According to Taswald himself, this workshop was 'a failure', yet it successfully

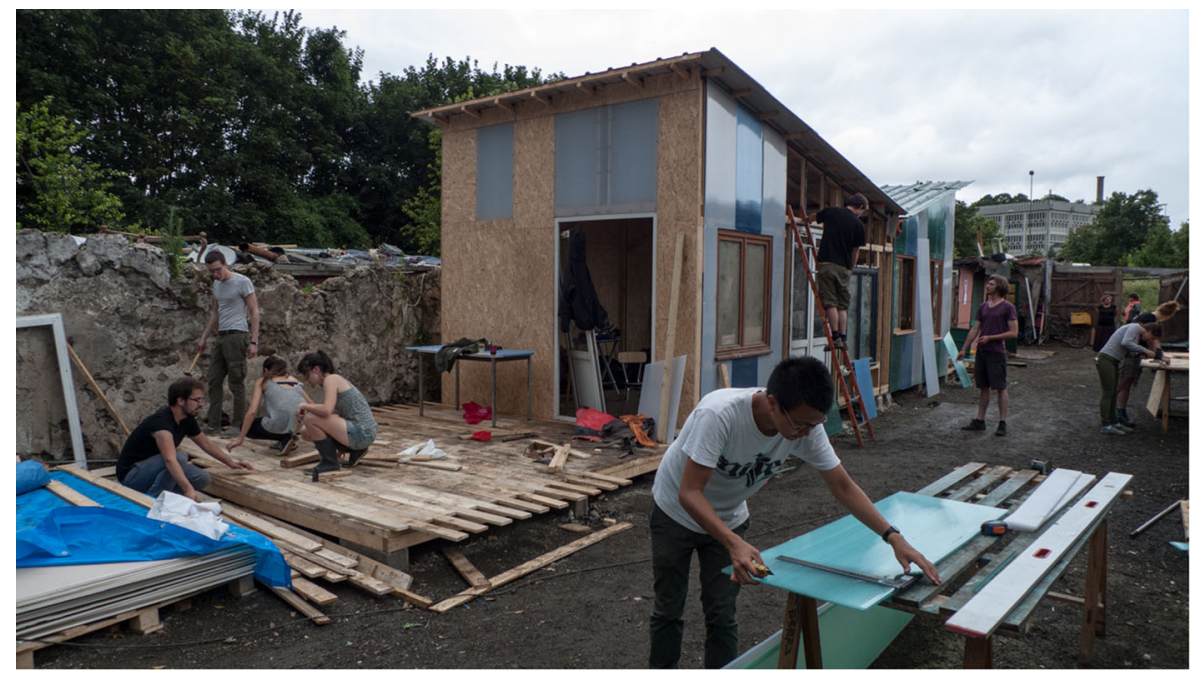

Fig. 1 Students working on the construction of a community building, Montreuil, Paris. The first build, a bathroom, responded to an urgent need that the residents themselves identified. However, a consecutive kitchen project had been offered as a 'gift' to the Roma as they were a 'target group' of the architectural school. This too was problematic as it did not fit with gendered Roma traditions of cleanliness and cooking 
showed him that he still had to spend more time with the family in order to construct the

'true participation' he was aiming for (Rojas Loa 2015, pp. 88-89).

Pillay purposefully delayed construction and initiated a group discussion between the residents and the agencies working with them. In this way he identified what was needed from a 'community building'. As a result of this dialogical process, additional partners were brought in to work with the residents on their social and economic needs: running furniture making workshops for men and printing workshops for women to that would create new opportunities to earn an income. For the architectural students, Pillay's Montreuil residency generated learning in practice. Anna Recalde, responsible for facilitating the trans-local dialogue of this residency within the 9UB network, suggested it was 'a little revolution' for the students of the architecture school: 'to 're-consider' a proposed design all the way to 'handing over decisions" was certainly a new and challenging experience (cited in Rojas Loa 2015, p. 89).

This brief example of a collaborative urban encounter holds many lessons. In many ways the Montreuil residency can ostensibly be read as a series of failures: the conceptual failure of generalising notions of 'community' (Huygues 2015; Minod 2015); the failure of involved parties to understand each others motivations or to interrogate the governmentality inherent in the nature of the invitation; the failure to engage with and respond to the everyday spatiality of Roma family life. Yet in other ways it can be read as an example of a success. Pillay and Quatorze halted the architectural action and succeeded in bringing about a considered dialogue between all parties. This dialogue established new conditions for collaboration. Pillay's critical social architectural practice reconfigured the actors and their perspectives on the urban (Sitas and Pieterse 2013, p. 332). His critique challenges the widespread orthodoxy amongst design professionals that material interventions on their own can prompt lasting social improvements. This example generated a sociological interruption of an architectural intervention, by providing secure space and time for an 'arena of exchange' between the Roma family and those who sought to work with them (Horn 2015, p. 8). Pillay's Montreuil residency illustrates the ways that even thoroughly planned and well-intentioned urban interventions are filled with the complexity and micro-politics of everyday life. It exemplifies the hazards of de-historicised and depoliticised engagements with 'the other', which have been symptomatic of the global interest in African urbanism (Parnell 2015; Gandy 2005). It points towards the disciplinary power inherent in urban development projects. It also illustrates some of the gains and losses associated with visibility in the city (2004). Most significantly however, for the purposes of this paper, it points to the pitfalls and possibilities of collaboration.

The Montreuil residency was one of nine artist residencies that sit at the centre of an international urban arts and research intervention 'Nine Urban Biotopes' (9UB) [1]. The aim of 9UB was to employ socially engaged art practice in order to foster both local and trans-local learning conversations on the theme of 'negotiating the future of urban living' (Horn 2015). 9UB took place across seven cities in South Africa and the European Union between 2013 and 2014. The project was established on the basis of 9,3-month-long residencies in which South African creative practitioners (artists, architects and cultural workers) engaged in European urban situations whilst European creative practitioners engaged with South African urban situations. These residencies were hosted by small NGO's, cultural and university institutions or not-for-profit socially engaged agencies. Hosting partners facilitated these exchanges in the context of their long-standing social engagements with neighbourhood groups and local 
publics. 9UB conceptualised these local hosting arrangements as 'urban biotopes'. The artist residencies were brought into dialogue with local urban contexts 'on street level', with other 9UB residencies, with project partners and with cultural institutions. These South-North encounters responded to issues of urban regeneration and development, community safety, migration, housing, and economic subsistence, in the thick of everyday urban life, in the seven host cities. 9UB was, in effect, a generative impetus for ongoing and pre-existing social initiatives, rather than a container for a set of temporally fixed projects of social engagement. ${ }^{1}$ The project engaged local publics through events, discussions and the interventions themselves. Its public face was also realised digitally through a purpose-built website which was updated weekly as the project unfolded. At the end of the project, an electronic publication was produced. ${ }^{2}$ Alongside the time-limited biotopes (the residencies and associated encounters), 9UB's funders and partners reflected on these local approaches to global problems of urban sustainability and development on both sides of the equator.

This paper takes two 9UB residencies as examples of collaborative arts and research practice, both of which could be simultaneously read as 'failures' and 'successes' and which dramatise the complexities of North-South collaborations. This project, the partnership that sustained it and the residencies that were central to it, exemplify, in modest ways, global public sociology in practice. 9UB was subject to scrutiny through evaluative research ${ }^{3}$ as is the norm with publicly funded interventions. This was carried out by the author. This role was one of creating protected time and space where relations of trust, shared learning, debate and reflection could flourish. This critical and collaborative approach to evaluation diverges significantly from the orthodoxies of evaluative research that seek to evidence success through prescribed externally generated standards. Instead the 9UB evaluation aimed to provide space where disagreement could be identified and discussed and contrasting senses of failure and success could be shared and debated.

The paper focuses on a series of interdisciplinary urban interventions to illustrate how public sociology can be realised in modest ways in a global context. We argue that this is made possible through the principles of dialogue, collaboration and reflexivity. This paper shows, with examples, that whilst partnership and collaboration are emphasised in institutional and policy discourse, in practice these arrangements are filled with tension and unequal power relations between partners. An evaluative methodology premised on sociological practice allows the tensions that are inherent in partnership and collaboration to be recognised and

\footnotetext{
${ }^{1}$ This distinction between ongoing initiatives and one-off projects was suggested by Doung Jahangeer, founder of dala art/architecture, host to the 9UB intervention in Durban (Notes from 9UB kick-off meeting in Paris, September 12th, 2012).

2 The 9UB e-book can be down loaded as a PDF at http:/www.urbandialogues.de/uploads/pdf/biotopes/ 9UBePublicationflat.pdf. It is also available as an e-book with 'click through' multi-media contents through Google Play and iTunes.

${ }^{3}$ Within the discipline of sociology project or programme, evaluation is often looked upon as insufficiently critical, methodologically unsound and complicit with the disciplining logic of neoliberal governmentality (Belfiore and Bennett 2010; Yudice 2003; Lees and Melhuish 2015). Conducting evaluative research in the field of the arts has clear political implications given that evaluation is an apparatus of instrumentality, accountability and the management of the cultural sector. It exemplifies the troubled relation between the culture and the recognition of its economic value. The research methodology was therefor carefully attuned to the spirit of the project, and conducted in a way that contributed to, the realisation of the projects ambitions rather detracting from them. This ethos was central to the sociological evaluation. Rather than advocating for the project partners or evidencing success, the 9UB evaluation sought to prompt discussion and translocal dialogue between partners whilst conducting a formative and reflexive evaluation.
} 
productively interrogated. It also allows us to reimagine what 'success' and 'failure' looks like in research partnerships by working with the antagonisms that are integral to collaboration.

\section{Introduction: Collaboration and Its Disciplinary Manifestations}

The turn to participative and collaborative working practices, as found in $9 \mathrm{UB}$, arise out of a desire to do things better by doing things together. These tendencies are frequently found in spatial disciplines and practices such as architecture, planning and design. They emerge out of a critique of 'top-down' practice and the failure of architectural solutions to address urban problems. 1990's spatial critique was concerned with the social and cultural complexity of urban space (for example in the work of Zukin 1991; Davis 1990; Sorkin 1992). Participation offers way of empowering the users of urban space for architects and planners who seek to produce locally appropriate spatial solutions to urban problems realised through democratic processes of dialogue, negotiation and consensus. This turn towards participation (a logic which is frequently twinned with collaboration) is also prevalent in the art world. It is found in a range of practices which are concerned with collaborative action. This may be through collaboration with a social group or 'community', a social context, or with other creative practitioners and researchers. The socially engaged art practice, found at the centre of 9UB, can be traced back to several artistic traditions ${ }^{4}$ including the community arts movement which emphasised cultural democracy (Braden 1978; Kelly 1984). However, socially engaged practice also evolves out of critical debates around the role of the artist in society, which are found in the work of the Artist Placement Group (see Bishop 2012), 'new genre public art' which emphasises public engagement over spectatorship and art making as a practice of research and knowledge production (Lacy 1995), and site-specific art (Kwon 2002). Bourriaud's Relational Aesthetics (1998) places an emphasis on site, events, performance and participation. 9UB in some senses can be understood through theories of Relational Aesthetics in that 'modest connections, open up (one or two) obstructed passages, and connect levels of reality kept apart from one another' (Bourriaud 2002, p. 8), producing 'social interstices' that 'tighten the space of social relations' (2002, p. 15). Relational Aesthetics (2002) argued for 'an art taking its theoretical horizon the realm of human interactions and its social context, rather than the assertion of an independent and private symbolic space human interactions, and their social context rather than art as being the matter of asserting an independent and private symbolic space' (Bourriaud 2002, p. 14). Rather than being confined to the studio, socially engaged art is concerned with, and located in social contexts, working collaboratively with social actors.

This 'social turn' (Bishop 2006) brings arts practice into a more committed relation with social reality. It emphasises an aesthetic premised on dialogue and is concerned with the ethics of participation and collaboration (Kester 1999, 2004, 2011; Bishop 2004, 2006, 2012). These practices have received considerable critical attention in regard to the relationship between art practice, research outcomes, curating and commissioning and place (O'Neill and Doherty 2011), the societal context of revived interest in community art (De Bruyne and Gielen 2011), the connection between arts production and curational practice and audience, and the pedagogical practices of gallery education (O’Neill and Wilson 2010; Morsch 2011). Considerable

\footnotetext{
${ }^{4}$ This paper does not allow sufficient space to offer a full account of the complex roots of socially engaged art practice. For a summary, see Bradley and Esche (2008) and Thompson (2012).
} 
critical attention has focused on the political and ethical implications of socially engaged art practice as artists are increasingly tasked with restoring the social bond (Rancière 2006, p. 57). Culture, as George Yúdice (2003) argues, is an expedient resource providing a source of economic growth, and a solution to the problems created by neoliberalism's negative social effects. Critics of this instrumentalising and governmental use of socially engaged art practice in the context of neoliberalism (Jelenek 2013; Leger 2013) argue that funded cultural interventions, such as 9UB, place artists in a difficult position. As Leger argues, 'in this context artists and activists unwittingly become 'willing executioners' of public management and development experts whose main concern is that culture produce a return on investment' (Leger 2013, p. 20), whilst enhancing their corporate social responsibility.

\section{UB and Sociological Collaboration}

9UB was a project that had 'trans-local dialogue' (Horn 2015) at its core. This was the basis for cooperation from the outset. Robust and lively conversation was crucial for the delivery and longevity of local interventions and the trans-local learning they generated. Facilitating this trans-local North, South dialogue was principal to the work of the academic partners. This ongoing research and reflection connected the activities of each biotope with other sites in the network with an aim of exposing, discussing and sharing different intentions, methods and techniques realised through the project. Throughout this process, we worked to enliven 9UB's 'arena of exchange' through critical dialogue: a principle intention and methodology of 9UB, and therefore our evaluation criteria. We, as academic partners, paid attention to the processes that do (or do not) make dialogue possible. We attended to the forms and conditions of dialogue: what is required from those who wish to take part in it, the extent to which partners come together, and the diverse understandings of cultural practice that are tested and made apparent in the dialogical process. In a sprit of criticality, the academic team worked with an awareness that dialogue is not merely a matter of coming together in agreement. 9UB was made up of a complex constellation of actors, desires, motivations, intentions and actualisations. These gradually aligned in the work of designing, co-producing, distributing and disseminating the socially engaged practice at the heart of the project. Consequently, 9UB was surrounded also by partner expectations and investments, which were at once tactical and strategic, political, aesthetic, affective and economic. Our work, as sociological partners, entailed drawing out the differences and disagreements and working productively with them. This was a process of recognising the agonism of the project ${ }^{5}$ in the belief that infrastructures filled with liveliness and 'agonality' are necessary conditions for flourishing dialogue between partners in the North and South. This was realised in practice through meetings with commissioners, partners, host organisations and artists, and holding regular feedback sessions, dialogical encounters with other involved stakeholders, multiple in-depth interviews, and sharing written reflections, attending and contributing to public events with local publics. This created a public sociological dialogue that unfolded before, during and after the delivery of the residencies.

\footnotetext{
5 As Mouffe and Laclau argue, this 'agonality', or 'battle of meaning', is as appropriate as consensus in radical democracy (Laclau and Mouffe 2001. It is also integral to the ways in artistic interventions in public space can 'create a multiplicity of sites' where the neoliberal hegemony can be confronted, questioned and the desire for change can be aroused (Mouffe 2013, pp. 85-106; Mouffe 2001).
} 


\section{The Soweto Residency: Ubuntu Park as a 'Relational Object'}

The following example illustrates the sociological practice that created a space for dialogue, learning and reflection. As with the Montreuil residency, here the parameters of success and failure are complex and contested. Whilst Pillay brought his Southern expertise to a temporary settlement in the north and disrupted the architectural orthodoxy, here Berlin-based artist Marjetica Potrč encountered an equally complex social and spatial formation that made apparent the contrasting cultural values of institutional partners and sponsors, the challenges facing practitioners from the North working in the South and the value of sociological dialogue in making sense of this.

Marjetica Potrč, together with students from the Design for the Living World class at the Academy of Fine Arts, Hamburg, took up a 3-month residency in Orlando East, Soweto, Johannesburg. Here, Potrč initiated and implemented the transformation of a derelict, open space into a 'park-in-formation' (now referred to as Ubuntu Park). This intervention consisted of preliminary neighbourhood workshops, a collective neighbourhood cleaning event, planting and nursing trees, and the DIY instalment of park equipment including benches, tables and a stage (see Fig. 2).

Underpinning this spatial transformation, regular meetings were held on-site with the aim of jointly envisioning and articulating the future of the park. The open 'quality of invitation' (Rooke 2014, p. 05) to the process brought together a network of participants that included neighbours, local interest groups and political representatives. A steering committee was formed and decisions concerning the park were taken together, on-site, at public meetings. Together artists and neighbours learned about local political culture by sharing new and old, good and bad experiences: jointly 'feeling their way forward' and collaboratively learning 'the rules of the game' (Bourdieu and Waquant 1992). The Soweto residency raised awareness of spatiality: the ways that the social and the spatial are inextricably entwined in each other (Soja 1996). In this process, the group researched the 'power geometry' (Massey 1991) of the site and its relationship to political interests. In this process, they began to develop the knowledge, skills and forms of social and cultural capital required to have local influence. More than being

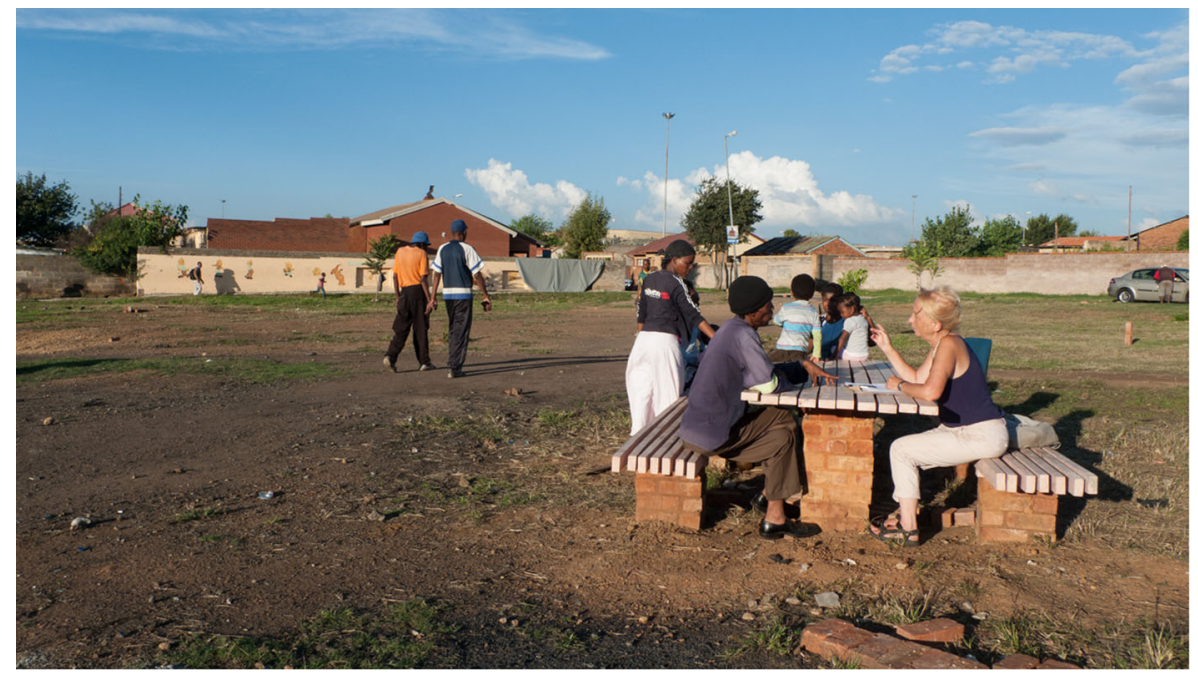

Fig. 2 Marjetica Potrč, with local residents in the 'park-in-formation' Orlando East, Soweto 
(merely) a park, the 'outcome' of the process was a modest learning experience of how to realise urban change. Drawing on Sitas and Pieterse's analysis of comparable urban public art projects, 9UB's 'park-in-process' can be understood as a 'platform of affective democratic imagining' (Sitas and Pieterse 2013, pp. 328-329). The local group together with Potrč and the Design for the Living World class reflected on the future of this public space given its violent history during apartheid and South Africa's fractional wars of the early 1990s. In imagining a future for the space, this intervention brought about shared learning on how to access and participate in formal structures and processes of local governance (in particular the South African Integrated Development Planning (IDP) process and Ward Committee System). It also entailed learning to navigate the hierarchies of age and gender found in internal group politics.

Whilst witnessing and encouraging these conversations, we played a vital role in raising questions of uneven access to participation that are rooted in race and class and that materialise as poverty and marginalisation in space. Through group and individual conversations before, during and after Marjetica Potrč's residency, we identified the divergent and conflicting roles, aims and expectations of the project's stakeholders. Debates regarding the future of the park, in terms of both the material improvement of the area and as a 'relational object' (to use Marjetica Potrč's term), brought the neighbourhood group together.

These conversations were ongoing 6 months later on a return research visit after the residency had ended. At the end of the 3-month residency, local people were left to take forward the visions for the park. However, making collective decisions about how to move forward became the group's principle obstacle. Unfortunately, the host organisation that had introduced the artist residency to its social context so carefully in the beginning, was unable to support and to build on the achievements of Potrč's experimental civic practice. Given this lack of progress, the extent to which this residency could be considered a success was contested. This was apparent in responses from two South African sponsoring institutional partners. Whilst one criticised the subsequent poor condition of the park (stating 'there is nothing there'), another celebrated the case as an example of 'best practice' in public safety and social urban development. Some perceived the Soweto residency as a naive Eurocentric misreading of the socio-cultural context and the 'quality of the invitation' (Rooke 2014), whilst for others it exemplified a 'school of applied learning'. The wide gap between these perceptions reflects divergent cultural policy agendas, degrees of local knowledge and associated international development paradigms. They are also indicative of the contestations surrounding socially engaged art practice, which is characterised by its complex, contradictory and unconventional outcomes and aesthetic criteria. Our sociological practice involved drawing out these discussions and disagreements, and making them an explicit part of the 9UB dialogue. In this process, antagonisms between the global development paradigms of cultural partners and local perceptions on the ground were acknowledged ${ }^{6}$. Here, sociological practice was a matter of instigating and engaging in open-ended dialogue and reflection on the past, presence and future of the local, and sharing these reflections translocally.

\footnotetext{
${ }^{6}$ In a similar reading, Wanjiku concludes: 'In a way, Ubuntu Park is about the rewriting of a community's history. It moves beyond the materiality of the park, its benches, braai (barbeque) stands and concrete stage. Indeed, the park's realisation touched at the heart of a deep-seated questioning of self and community, history and future, empowerment and disempowerment' (Wanjiku 2015, p. 62).
} 


\section{Collaborative and Dialogical Research Practice}

9UB contains many examples of socially engaged artists using artistic methods to explore social reality, produce spaces for critical reflection and debate, and to attempt to change urban conditions at the local level. Collaboration was integral to all aspects of the project's realisation including collaboratively conducting research. Collaborative research was not merely a matter of sociologists doing conventional social research with others. The 9UB artists were tasked with researching the social and cultural context of their residency, and creatively and critically responding to it, using 'live' methods and artistic social research (Back and Puwar 2012; Sullivan 2005; Finley 2008; Wesseling 2011). Here, the professional practices of artists and ethnographer overlap. Each of these face the challenges of access, establishing rapport, gathering the raw materials or 'data' for subsequent analysis and developing representational strategies and offering a critical perspective on the social world they are concerned with. Rather than producing an academic text as a research outcome, the artists working within the 9UB biotopes created, in Bourriard's terms, a social interstice '[A] space in human relations which fits more or less harmoniously and openly in the overall system, but suggests other possibilities than those in effect within this system' (Bourriaud 2002, p. 160). These are modest examples of the possibilities of doing global sociology through collaborative and creative research practice and critical dialogue. The critical reflection on 9UB from various stakeholders was concerned with these 'social interstices': the kind of urban futures they point to, the interpersonal relations they represent, produce or prompt (Bourriaud 2002, pp. 12-13). ${ }^{7}$ The artist has a reflexive function within a socially engaged project, testing the possibilities for knowledge production.

Critical dialogue was also central to the sociological practice of 9UB. This emphasis on dialogue, as Kester argues (drawing on Bakhtin's (1981) theory of dialogism), shifts the theorization of art from an emphasis on the individual experience of spectatorship of the visual, or the sensory encounter with the art object, to 'the condition and character of the exchange itself' (Kester 1999). In doing so, he draws our attention to the 'politics of the social process, relations of collaboration, exchange and negotiation' (Kester 1999). Dialogism is not merely a matter of engaging in conversation with another, but rather a matter of understanding one another's cultural practice and using this understanding to perceive and re-perceive the self and our own social and cultural constellations. It is a matter of the 'intersubjective quality of all meaning', or, as Hirschkop expounds, about 'the space between expression and understanding' (Hirschkop 1999, p. 4). As 9UB illustrates, socially engaged art practice can materialise this inbetween, or interstial space, and work with its dialogical potential. It provides 'a locus of differing meanings, interpretations, and points of view' (Kester 2004, p. 10). As discussed above, critical dialogue was foregrounded as a principle intention and methodology of 9UB, and therefore an evaluation criteria. In summary, 9UB exemplifies a 'translational mode of working' (Parnell 2015), combining creative practice on the ground, research, ongoing multilevel dialogue and reflection and debate. This translational practice is one challenge of internationalisation in urban higher education, in that it:

[E]ncompasses the integrating [of] research conception, design, execution, application and reflection - and conceiving of this set of activities as a singular research/practice

\footnotetext{
${ }^{7}$ There is insufficient space here to thoroughly interrogate the parallels between these art collaborations, which aspire to produce situations in which diverse actors come together to produce some degree of social change, and traditions of Participatory Action Research (Fals-Borda and Rahman 1991) and critical pedagogy (Freire 1982).
} 
process that is by its nature deeply political and locationally embedded (Parnell, Urban

Lab Plus 2015, p. 10).

\section{Conclusion. Collaboration in Today's Educational Landscape}

9UB with its European/African partnership structure and interdisciplinary team provides is one relatively small example of the kind of initiatives that are possible within the international research and educational policy landscape. Research partnerships between higher educational institutions and non-academic partners are increasingly favoured by funders. They are seen as fostering relationships between institutions, across disciplines, offering good value for money, less replication and knowledge exchange (see Katz and Martin 1997; Griffin et al. 2003). Successful partnerships rely on collaboration and dialogue. The drive towards research partnerships can be understood as an opportunity for developing a public sociology. This is premised on sharing the knowledge of what Burawoy describes as the 'professional sociologist' with diverse publics, includes civil society organisations, institutions and local groups. Public sociology is also concerned with how to work reflexively with diverse publics in dialogue to produce sociological knowledge (Burawoy 2005). As Chase Dunn argues, 'Burawoy's most important precept of public sociology endorses direct interaction with, and participation in, civil society groups, and research that is directed toward helping these groups achieve their goals' (Chase-Dunn 2005, p. 9). Advocates for public sociology argue that engagement beyond the academy is both a moral imperative and in the interest of the discipline (Braithwaite 2005; Calhoun 2005; Etzioni 2005; Kalleberg 2005). It offers the potential of producing sociology that is relevant, accessible and importantly valid (Scott 2005). As Scott argues:

The key task for public sociology, then, is to establish the means through which publics are motivated to take seriously and to engage with its academic products. This is a slow, incremental process in which people must be persuaded and enticed into reading sociology and, most importantly, thinking sociologically (Scott 2005, p. 408).

Public sociology is also a matter of working from a position that generates a multifaceted and complex understanding of social context (see Hale 2008). Existing institutional arrangements do not make this kind of public sociology-founded on direct partnership, collaboration and dialogue with civil society-a desirable proposition for many scholars. This is in part due to the culture of professional sociology, and its indicators of excellence and esteem which prioritise writing and scholarship aimed at other professional sociologists (Sprague and Laube 2009; Scott 2005). Along with the drivers for partnership, prevalent in the research funding landscape, the internationalisation of Higher Education provides opportunities for developing collaborative sociological practice across North South borders. As Northern universities expand as part of a global market in a 'world hierarchy of urban cosmopolitan centres' (Melhuish 2015, p. 5), a 'global-North-in-the-global-South' dynamic is developing, whereby North European, North American and Australian universities open campuses and centres in South Asia, the Middle East and Southern Europe in an attempt to reach lucrative new markets. These developments raise questions about the impact of the 'internationalisation of education' on the cities hosting these global 
university campuses. ${ }^{8}$ This globalised educational landscape offers challenges to Eurocentric sociological theory. These include the pressing need to recognise the Eurocentric and self-referential orientation of the sociological tradition ${ }^{9}$ (Bhambra 2013; Sorokin 2016) to recognise and pay critical attention to 'epistemologies of the South' (de Sousa Santos 2014) and to acknowledge how the material and institutional conditions of the Global North shape the production of academic sociological knowledge. This globalised educational landscape also offers challenges to sociological practice and recognising the limits of 'academic sociology' and its 'a priori unequal conditions of interaction' (Sorokin 2016, p. 8). ${ }^{10}$ There are opportunities to be seized in this globalised educational landscape. These are exemplified by $9 \mathrm{UB}$, a project that unfolded in a context shaped by the unequal power of large institutions and small organisations. Each of the project partners were motivated by a desire for institutional recognition and validation, yet were differently placed to realise these desires. This is the complexity of this kind of partnership work. 9UB's multimodal representational strategies avoided 'the 'cultural orthodoxies' of the academic imagination' (Keith 1992, p. 551) whilst successfully engaging academics and their publics in a lively conversation between the Global North and South.

Our involvement in 9UB exemplifies these tensions between public and professional sociology. Financially, this was a modest project and was reliant on academic time being offered as 'match funding'. This kind of research and its outputs do not carry a great deal of esteem within the hierarchies of the university and its indicators of excellence, despite an ostensible commitment to 'collaboration'. And yet, it is precisely this kind of research that embodies a commitment to collaborative sociological practice, and which requires considerable skill in the art of listening (Back 2007) and translation (Parnell 2015). 9UB's evaluative research was, in some senses, what Burawoy calls 'policy sociology', in the sense that it was tasked with evaluating the delivery of an aspect of cultural policy. However, as this article has shown, the sociological practice at the heart of 9UB was not merely policy sociology, but rather an act of enlivening the debate amongst multi-level, translocal sociological publics. In a spirit of criticality, we worked with an awareness that dialogue is not merely a matter of coming together in agreement, nor is evaluation merely advocacy. Our work, as sociological

\footnotetext{
${ }^{8}$ As Wiewel and Perry point out: 'The urban location and centrality of universities to the nature and wellbeing of cities means that cities and countries can be expected to turn to their universities as part of strategies to respond to the new challenges and opportunities that global economic competition poses for urban regions' (Wiewel and Perry 2008, p. 304). Whilst those responsible for city governance may welcome collaborations with universities from the global north, their impact on less powerful national urban institutions and actors may be less welcome, including local educational institutions and local communities (see Campkin et al. 2014).

${ }^{9}$ The limits of transplanting sociologies developed in the Global North to the South African context is highlighted in an exchange between Burawoy and von Holdt (2012) concerned with 'Northern' and 'Southern Theory'. This dialogue, described as the 'Johannesburg Moment', was an attempt to 'disorder and reorder Western theory so that it is better able to name South African realities'. Burawoy and von Holdt call for the reworking of sociological theory; in short, to 'provincialise Europe' (ibid 2012, p. 6; see also Bhambra 2013). Von Holdt and Burawoy argue, for example, that Bourdieu's theories of symbolic domination were not very influential in apartheid-era South Africa. Instead, in the context of physical violence and oppression, Marxist theories of struggle and change had stronger public appeal and were readily taken by workers and activists. Gramsci, Fanon and Freire offered theories that made better sense of these conditions. Burawoy and von Holdt's conversations, together with related critiques of 'Northern Theory' (Connell 2007) have renewed relevance in the context of internationalisation of higher education and the drive for 'world class' universities.

${ }^{10}$ See for example the Times Higher Educational Rankings which judge world-class universities across teaching, research, knowledge transfer and international outlook (which included international collaborations, domestic to international student ratio's, faculty, publications, and research influence).
} 
partners, was a matter of drawing out differences, acknowledging the simultaneity of failure and success and working productively with this. Here, diverse understandings and expectations of art, its purpose, its acceptable manifestations and the cultural policy that surrounds it were tested, stretched and made apparent through dialogical process that recognised the agonism integral to the project. By animating social infrastructures and filling them with liveliness (and sometimes difficult conversations), we can create the necessary conditions in which sociological dialogue can flourish.

Open Access This article is distributed under the terms of the Creative Commons Attribution 4.0 International License (http://creativecommons.org/licenses/by/4.0/), which permits unrestricted use, distribution, and reproduction in any medium, provided you give appropriate credit to the original author(s) and the source, provide a link to the Creative Commons license, and indicate if changes were made.

\section{References}

Back, L. (2007). The art of listening. London: Berg.

Back, L., \& Puwar, N. (2012). A manifesto for live methods: provocations and capacities. The Sociological Review, 60(Supplement 1), 6-17.

Bakhtin, M. (1981). The dialogic imagination: four essays. Austin: University of Texas Press.

Belfiore, E., \& Bennett, O. (2010). The social impact of the arts: an intellectual history. Basingstoke: Palgrave Macmillan.

Bhambra, G. K. (2013). The possibilities of, and for, global sociology. In J. Go (Ed.), Postcolonial sociology: political power and social theory (pp. 295-314). Bingley: Emerald Publishing Group.

Bishop, C. (2004). Antagonism and relational aesthetics. October Magazine, 110, 51-79.

Bishop, C. (2006). The social turn: collaboration and its discontents. Artforum: 178-183.

Bishop, C. (2012). Artificial hells: participatory art and the politics of spectatorship. London: Verso.

Bourdieu, P., \& Waquant, L. (1992). An invitation to reflexive sociology. Chicago, IL: University of Chicago Press.

Bourriaud, N. (2002). Relational aesthetics. Dijon: Les Presses du réel.

Braden, S. (1978). Artists and people. London: Routledge.

Bradley, W., \& Esche, C. (Eds.). (2008). Art and social change: a critical reader. London: Tate.

Braithwaite, J. (2005). For public social science. The British Journal of Sociology, 56(3), 345-353.

Burawoy, M. (2005). For public sociology. American Sociological Review, 70(1), 4-28.

Burawoy, M., \& von Holdt, K. (2012). Conversations with Bourdieu: the Johannesburg moment. Johannesburg: Wits University Press.

Calhoun, C. (2005). The promise of public sociology. The British Journal of Sociology, 56(3), 355-363.

Campkin, B., Melhuish, C., \& Ross, R. (Eds.). (2014). Heritage and renewal in Doha: urban pamphleteer \#4. London: UCL Urban Laboratory.

Chase-Dunn, C. (2005). Global public social science. American Sociologist, 36(3-4), 121-132.

Connell, R. W. (2007). Southern theory: social science and the global dynamics of knowledge. Cambridge: Polity.

Davis, M. (1990). City of quartz: excavating the future in Los Angeles. London: Verso.

De Bruyne, P., \& Gielen, P. (2011). Community art: the politics of trespassing. Amsterdam: Valiz.

Etzioni, A. (2005). Bookmarks for public sociologists. The British Journal of Sociology, 56(3), $373-378$.

Fals-Borda, O., \& Rahman, M. A. (1991). Action and knowledge: breaking the monopoly with participatory action research. New York: Intermediate Technology Pubs/Apex Press.

Finley, S. (2008). Arts-based research. In G. Knowles \& A. Cole (Eds.), Handbook of the arts in qualitative research (pp. 71-81). London: Sage Publications.

Freire, P. (1982). Creating alternative research methods: learning to do it by doing it. In B. Hall, A. Gillette, \& R. Tandon (Eds.), Creating knowledge: a monopoly? Participatory research in development. New Delhi: Society for Participatory Research in Asia.

Gandy, M. (2005). Learning from Lagos. New Left Review, 33, 37-52.

Griffin, G., Brainström-Öhnan, A., \& Kalman, H. (2003). The emotional politics of research collaboration. Oxford: Routledge. 
Hale, C. R. (2008). Introduction. In C. R. Hale (Ed.), Engaging contradictions: theory, politics, and methods of activist scholarship (pp. 1-28). Berkeley: University of California Press.

Hirschkop, K. (1999). Mikhail Bakhtin: an aesthetic for democracy. Oxford: Oxford University Press.

Horn, S. (2015). One project and two continents. In S. Horn (Ed.), Nine urban biotopes: negotiating the future of urban living (pp. 7-20). Berlin: Urban Dialogues.

Huygues, F. (2015). Response by Abbé Pierre Foundation. In S. Horn (Ed.), Nine urban biotopes: negotiating the future of urban living (pp. 97-98). Berlin: Urban Dialogues.

Jelenek, A. (2013). This is not art: activism and other 'not-art'. London: I.B. Taurus.

Kalleberg, R. (2005). What is 'public sociology'? Why and how should it be made stronger? The British Journal of Sociology, 56(3), 387-393.

Katz, J. S., \& Martin, B. R. (1997). What is research collaboration? Research Policy, 26(1), 1-18.

Keith, M. (1992). Angry writing: (re)presenting the unethical world of the ethnographer. Environment and Planning D: Society and Space, 10(5), 551-568.

Kelly, O. (1984). Community art and the state: storming the citadels. London: Comedia.

Kester, G. (1999). Dialogical aesthetics: a critical framework for littoral art variant 9. Variant issue 9. Available from: http://www.variant.org.uk/9texts/KesterSupplement.html. Accessed 29 Oct 2015.

Kester, G. (2004). Conversation pieces: community and communication in modern art. Berkeley: University of California Press.

Kester, G. (2011). Contemporary collaborative art in a global context. Durham: Duke University Press.

Kwon, M. (2002). One place after another: site-specific art and locational identity. Cambridge: MA. USA. MIT Press.

Laclau, E., \& Mouffe, C. (2001). Hegemony and socialist strategy: towards a radical democratic politics (2nd ed.). London, New York: Verso.

Lacy, S. (1995). Mapping the terrain: new genre public art. Seattle: Bay Press.

Leger, M. (2013). The neoliberal undead: essays on contemporary art and politics. Alresford: Zero Books.

Massey, D. (1991). A global sense of place. Marxism Today, 38, 24-29.

Melhuish, C. (2015). University-led regeneration: introduction to the case studies. UCL Urban Lab 2015. Available from: https://www.ucl.ac.uk/urbanlab/docs/introduction-university-led-urban-regeneration. Accessed 29 Oct 2015.

Minod, R. (2015). Dialogue with Quatorze. In S. Horn (Ed.), Nine urban biotopes: negotiating the future of urban living (pp. 94-95). Berlin: Urban Dialogues.

Morsch, C. (2011). Alliances for unlearning: on the possibility of future collaborations between gallery education and institutions of critique. Afterall, 26, 5-13.

Mouffe, C. (2000). The democratic paradox. London: Verso.

Mouffe, C. (2001). Agonistics: thinking the world politically. London: Verso.

O’Neill, P., \& Doherty, C. (Eds.). (2011). Locating the producers. Amsterdam: Valiz.

O’Neill, P., \& Wilson, M. (2010). Curating and the educational turn. London: United Kingdom Open Editions.

Parnell, S. (2015). Translational global praxis: rethinking methods and modes of African urban research. In: Urban Lab Plus Global Urban Higher Education: the challenges and potentials of internationalisation. Available from: https:/www.ucl.ac.uk/urbanlab/docs/urban-lab-plus-symposium-programme. Accessed 29 Oct 2015.

Rancière, J. (2006). The politics of aesthetics: the distribution of the sensible. Oxford: Bloomsbury Continuum.

Rojas Loa, V. (2015). Building solutions. In S. Horn (Ed.), Nine Urban Biotopes: negotiating the future of urban living (pp. 86-92). Berlin: Urban Dialogues.

Rooke, A. (2014). Curating community: the relational and agonistic value of participatory arts in super diverse localities. (Available from http://www.ahrc.ac.uk/documents/projects-programmes-and-initiatives/curatingcommunity-the-relational-and-agonistic-value-of-participatory-arts-in-superdiverse-localities/Rooke. Accesses March 2016.

Rooke, A., \& von Wissel, C. (2015). Temporary public spheres: arenas of social participation in 9UB. In S. Horn (Ed.), Nine urban biotopes: negotiating the future of urban living (pp. 127-136). Berlin: Urban Dialogues.

Scott, J. (2005). Who will speak, and who will listen? Comments on Burawoy and public sociology. The British Journal of Sociology, 56(3), 405-409.

Sitas, R., \& Pieterse, E. (2013). Democratic renovations and affective political imaginaries. Third Text, 27(3), $327-342$.

Soja, E. W. (1996). Thirdspace. Malden (Mass.): Blackwell.

Sorkin, M. (1992). Variations on a theme park: the new American city and the end of public space. New York: Hill and Wang.

Sorokin, P. (2016). 'Global sociology' in different disciplinary practices: current conditions, problems and conditions. Current Sociology, 64(1), 41-59. 
Sousa Santos, B. (2014). Epistemologies of the south: justice against epistemicide. London: Routledge.

Sprague, J., \& Laube, J. (2009). Institutional barriers to doing public sociology: experiences of feminists in the academy. American Sociologist, 40, 249-271.

Sullivan, G. (2005). Art practice as research: inquiry in visual arts. Los Angeles: Sage.

Thompson, N. (2012). Living as form: socially engaged art from 1991-2011. Cambridge, Massachusetts: The MIT Press.

Wanjiku Kihato, C. (2015). Moving beyond materialism: rewriting community histories through socially engaged art in Soweto. In S. Horn (Ed.), Nine urban biotopes: negotiating the future of urban living (pp. 58-67). Berlin: Urban Dialogues.

Wesseling, J. (Ed.). (2011). See it again, say it again: the artist as researcher. Amsterdam: Valiz.

Wiewel, W., \& Perry, D. C. (Eds.). (2008). Global universities and urban development. Armonk: M E Sharpe.

Yúdice, G. (2003). The expediency of culture: uses of culture in the global era. Durham NC: Duke University Press.

Zukin, S. (1991). Landscapes of power: from Detroit to Disney World. California, USA: University of California Press. 